\title{
Regional development as a stimulator of competitiveness of the Polish economy
}

After the accession to the Communities, all new Member States were included in the cohesion policy. In practice, this meant supplying all areas of their social and economic life with European financial transfers. Poland, as the largest beneficiary of structural funds in 2004-2006, received almost EUR 13 billion from the European Union; in the next programming, the period between 2007 and 2013 it was over EUR 67 billion, and in 2014-2020 Poland will invest EUR 82.5 billion from the EU cohesion policy.

The vast majority of these funds went to the regions, hence the biggest beneficiaries were local governments at all levels. In this context, it is worth considering which of the EU-funded projects raised the competitiveness of the Polish economy and put it on the path of sustainable growth, and which were only spectacular pre-election initiatives generating costs. These questions are more important because the current programming period ending in 2020 is the last time when the less prosperous European regions will receive such significant funds from the Community budget.

\section{From the beneficiary of Community aid to participation in the $\mathbf{E U}$ regional policy}

With the collapse of the Eastern bloc, Poland and other countries of Central and Eastern Europe received economic aid in the form of the PHARE programme, which helped them alleviate the effects of the economic crisis and allowed them to rebuild inefficient real socialist economies into market economies.

From 1990 to the accession in 2004, Poland became the largest recipient of pre-accession Community assistance. Out of the sum of about EUR 16.5 billion, we received about a quarter of the pool of funds allocated to all beneficiaries. However, the scale of this support was uneven in different years. Thus, out of the EUR 3.916 billion that Poland received as a PHARE beneficiary in the years 1990-2003, only slightly more than 2 billion were received in the decade 1990-1999, while in the last four years of the programme's operation (years 2000-2003) we were granted over EUR 1.8 billion. This increase in the allocation of funds in the last years of PHARE's operation was caused by the upcoming accession to the European Union and the need for the widest possible range of European procedures necessary for the implementation of structural funds. The experience gained during its programming and absorption has been used in the EU implementation of cohesion policy (Sujkowska, 2005, p. 197). 
Despite the fact that Poland incurred enormous social costs in the process of preparing to join the EU structures, in the pre-accession referendum hopes for a better future for present and future generations prevailed. Accession aroused strong emotions both in public debates and in private conversations, and the most vividly discussed issue was the expected balance of benefits and costs of the EU membership. Opponents of integration saw it as a loss of independence and sovereignty. The supporters, on the other hand, saw accession as an opportunity to return to the European family and civilisational promotion, especially thanks to the absorption of EU funds, while at the same time trying to strengthen the political position in a united Europe. They stressed Poland's belonging to the Latin culture, accepted European solidarity, protection of the weaker, and the principle of the superiority of law over force, which is binding in the EU. In one generation we managed to achieve success: change the trajectory of the country's development and Poland's place on the political map of Europe.

\subsection{Implementation of the European funds}

Immediately after accession, the transfers of EU funds to Poland were insignificant due to the low level of advancement of preparatory procedures for the implementation of particular operational programmes. Only at the end of 2007, due to the accumulation of two programming periods, a much higher level of inflow of funds from the EU was recorded, reaching over EUR 6 billion annually, which constituted almost $2 \%$ of the Polish GDP. On average, in the years 2004-2009, the tranches of European funds for the implementation of the cohesion policy accounted at almost $4 \%$ of the revenues of the public finance sector and over 1.5\% of the Polish GDP (Wptyw, 2010, p. 33).

At the end of January 2009, the absorption of structural funds from the 2004-2006 programming period amounted to $92.4 \%$. On the other hand, there were delays in the disbursement of funds for the years 2007-2013, which resulted from the prolongation, at the EU level, of negotiations concerning the size and division of the EU budget for this period. Therefore, the actual start of the call for projects was not on the at the beginning of 2007, but towards the end of 2007. As a result, the level of funds absorbed was initially relatively low (5 lat, 2009, pp. 17-18).

Analysing the importance of the EU funds from the period 2004-2006 for the implementation of Poland's development objectives, it is necessary to state their positive impact both in macro and microeconomic terms. Over 88.6 thousand projects have been implemented, the vast majority of which have been successfully completed. On the other hand, the European funds increased in the next programming period, 2007-2013, really contributed to the economic growth and had a positive impact on the labour market. Compared to 2007, the Polish GDP was 18.2\% higher in 2012, which was the best result in the EU. The second fastest growing economy was Slovakia, which was a member of the eurozone, where the growth rate was $10.5 \%$.

In the 2004-2006 programming period, the majority of European funds were earmarked for co-financing infrastructure projects in the field of transport and environmental protection. As at the end of December 2006, the infrastructure projects were either built or modernised $-1,631 \mathrm{~km}$ of voivodship, poviat and commune roads, 
$1,286 \mathrm{~km}$ of waterworks and $1,240 \mathrm{~km}$ of the sewage system. However, at that time only $12.8 \mathrm{~km}$ of national roads were modernised, which should be regarded as a failure, as the modernisation of $350 \mathrm{~km}$ of these roads was planned. The main reason for the low use of EU funds earmarked for these investments turned out to be the specificity of the projects undertaken, their long implementation cycle, complicated legal and ownership system, as well as institutional and procedural barriers.

The largest and most effective group of beneficiaries of structural funds were local government units. This confirms the rightness of the concept of decentralisation of regional policy proposed by scientific and self-government bodies, carried out in the years 2007-2013 and subsequent programming plants. The vast majority of projects implemented by self-government units - about $92 \%$ of their value - were investments in basic infrastructure in Poland, which has been neglected for many years (Narodowe, 2007, pp. 13-15). Apart from self-government, an important place among beneficiaries of structural funds was occupied by entrepreneurs who allocated the obtained funds for the implementation of investment and modernisation projects, while the largest number of projects received support from regions with the largest number of registered business entities (Życki, 2005 pp. 27-28). At that time, though to a slightly lesser extent, the structural funds supported measures aimed at improving the quality of human resources (under the measures of the European Social Fund, support was granted to over 1,144 thousand people), development of the information society and co-financing of the research and development sector.

\section{Modernisation or procedures?}

The implementation of structural funds in Poland was entrusted to administration, but administrative structures, especially at a lower level, were initially not ready for their effective implementation, which translated into the quality of applications, and this, in turn, determined the quantity and size of European funds obtained. It was also a mistake, in the period immediately after the accession to the EU, excessive centralisation of the system and exaggerated rigorous procedures, which led to delays in the implementation of projects and programmes, and sometimes even their abandonment. The imposition by the Polish side of stricter requirements than those resulting from the EU practice resulted in real material losses in the form of a weaker use of aid.

The first months of accession revealed deficiencies in the beneficiaries' knowledge and experience in applying, implementing and settling projects, which required additional mobilisation of responsible institutions to conduct training and correct errors made by project providers. Not always in the case of training activities, the subject matter and profile of courses addressed to different groups of beneficiaries found substantive justification and met real needs. They were also often selected for the training of employees, treated as a form of distinction or award, and were not guided by the need to supplement knowledge and skills by persons responsible for EU projects.

The flow of information also proved to be a significant barrier. In the extremely complex system of implementation, there were noted delays related to decision making and slowness in transferring information to individual intermediary institutions. 
Announcements about competitions appeared at the last minute so that many potential beneficiaries were no longer able to prepare applications. This state of affairs resulted in the lack of project selection and the necessity to repeat the competition procedures.

Procedural and systemic solutions verified in practice were successively subject to adjustments aimed at eliminating burdens and barriers. In most cases, the changes consisted of clarifying the regulations or criteria for the use of assistance and simplifying documents. These changes contributed, on the one hand, to the facilitation and simplification of application and implementation procedures, and, on the other hand, they introduced continuous anxiety among beneficiaries, who often could not keep up with them. Forced to keep track of new procedures, decisions, interpretations and decisions, they lost patience and were discouraged from using the EU funds. On the other hand, the competition proceedings were dominated by an official diktat and no attempts were made to rationalise the allocated funds. Implementing institutions limited themselves to intuitive assessments of the importance of specific projects for a specific sector. This required further correction of errors and inconsistencies in documents, more accurate redistribution of funds to individual programmes and projects.

In the first programming period and at the beginning of the second, i.e. from 1 May 2004 to 31 December 2008, the transfers from the Union budget amounted to EUR 26.5 billion. At the same time, Poland contributed EUR 12.5 billion to the EU budget. The positive balance of financial flows from the Communities after five years of membership was therefore at the level of EUR 14 billion. The largest number of funds for the implementation of projects under the National Development Plan 2004-2006 was obtained by the richest voivodships and those with a large number of inhabitants, i.e. Mazowieckie, Śląskie, Dolnośląskie, Pomorskie and Wielkopolskie voivodships, and they also obtained the largest number of funds from the Cohesion Fund. In total, the beneficiaries in the five richest Polish voivodships received half of the funding available for the regions. The voivodships of eastern Poland obtained only $15 \%$ of the EU funds at that time (Wptyw, 2010, p. 33).

The payments to beneficiaries in the 2007-2013 programming period show the changes that took place during the implementation of the National Strategic Reference Framework in expenditure classified by category of structural funds interventions. While in 2008 the largest payments were made in the area of improving access to employment and its sustainability, in the following year payments were dominated by items related to the transport of almost PLN 5.6 billion and research and technological development (R\&D), innovation and entrepreneurship of over PLN 4.1 billion. The changes that took place in the levels of payments resulted from the increase in the level of implementation of measures in the Operational Programme Innovative Economy and, in the case of the transport area, in the Regional Operational Programmes and in the Operational Programme Infrastructure and Environment.

On the other hand, the share of expenditure on "soft projects" in the area of access to employment was much smaller and amounted to only $14 \%{ }^{1}$

For the period 2007-2010, cohesion policy expenditure (heading 1.2 of the EU budget - Cohesion for growth and employment) amounted to 143.6 billion euro, representing $30 \%$ of total EU expenditure over the period. As in the previous financial perspective,

\footnotetext{
${ }^{1}$ Data of the Ministry of Regional Development.
} 
cohesion policy is the second largest category of expenditure, after the common agricultural policy (Ocena, 2011, pp. 10-12). In the period 2007-2010, expenditure related to the implementation of cohesion policy in Poland financed by EU funds amounted to just over EUR 20.8 billion, and it is estimated that it accounted on average for $2 \%$ of GDP in that period. The largest amount of funds was allocated to the development of basic infrastructure - about EUR 12.1 billion, which accounts for $57.9 \%$ of the total expenditure. Almost 1/4 of the funds (over EUR 5 billion) were used for the implementation of projects related to direct support for the enterprise sector, and 18\% (EUR 3.7 billion) for the development of human resources (Raport, 2011, p. 25).

\section{Levelling out regional disparities}

When balancing all Community support, it should be stated that the allocation of the EU funds, apart from exports, had a decisive influence on the economic growth in Poland after accession to the EU. These funds reached a high level in 2011, when, after deduction of the contribution to the EU budget, EUR 10.5 billion was received from Brussels (an increase by nearly $36 \%$ in relation to the previous year), which was equivalent to approximately $3.2 \%$ of the Polish GDP. Membership contributions to the EU budget in 2011 amounted to EUR 3.7 billion, while transfers from Brussels amounted to over EUR 14 billion, in the form of structural funds, the Cohesion Fund, direct payments and other supporting instruments. The year 2012 turned out to be even more favourable in terms of transfers from the EU budget when Poland received EUR 11.9 billion (equivalent to $3.11 \%$ of the Polish GDP). The transfers of EU funds in 2013 were at a similar level, the amount of which per balance amounted to EUR 11.2 billion. The year 2014 turned out to be a record-breaking year, when revenues from the EU budget reached the level of almost EUR 13 billion, as shown in the table below.

Table 1

Financial flows from the EU to Poland in 2014 (in EUR)

\begin{tabular}{|l|r|}
\hline Structural Funds & $7,369,627,734$ \\
\hline Cohesion Fund & $4,524,540,951$ \\
\hline ISPA (Instrument for Structural Policies for Pre-Accession) & $54,857,443$ \\
\hline European Fund for the Most Deprived & $52,069,519$ \\
\hline Direct payments & $3,154,051,235$ \\
\hline Rural Development Programme & $1,772,534,433$ \\
\hline Market interventions & $37,417,966$ \\
\hline Other transfers of the Common Agricultural Policy & $12,259,946$ \\
\hline European Fisheries Fund & $132,430,236$ \\
\hline Migration funds & $8,181,820$ \\
\hline Other transfers & $6,631,360$ \\
\hline Total transfers & $17,124,602,643$ \\
\hline Membership fee & $4,153,101,502$ \\
\hline Reimbursements to the EU budget & $1,237,753$ \\
\hline Balance & $12,970,263,389$ \\
\hline
\end{tabular}

Source: Own elaboration based on data from the Ministry of Finance. 
The above data prove that Poland is still a net beneficiary of European funds, which has generated the possibility of achieving additional economic growth in the areas of construction and modernisation of infrastructure. Ex-ante estimates carried out in 2001 on the forecast of future economic development indicated the possibility of achieving additional GDP growth at the level of $1.3-2.1 \%$ annually by 2009 . According to ex-post evaluations, this additional economic growth averaged $1.75 \%$ per year in the new Member States in the period 2004-2008 (5 lat, 2009, p. 15). However, according to the Ministry of Infrastructure and Development, thanks to the use of the EU funds, the GDP growth rate in 2011 alone was higher than in the scenario without funds by about $0.6-0.8 \%$.

Overcoming Poland's civilizational backwardness required above all an increase in the country's spatial cohesion, which was achieved through the improvement of communication and technical infrastructure. At the same time, the condition of infrastructure was and still is very diverse in particular regions and this is the cause and effect of the level of development of these voivodships. Five regions of eastern Poland (podlaskie, warmińsko-mazurskie, lubelskie, podkarpackie and świętokrzyskie) are still among the 20 poorest regions in the Union, with GDP per capita between 41 and $47 \%$ of the EU average. On the other hand, it should be stressed that all these "weak" voivodships in the 2007-2013 period were characterised by a GDP per capita growth rate higher than the EU average and they were among the top 30 regions with the highest growth in the Union. Despite the fact that the interregional differences in the country are significant, in fact they are not greater than in the "old" EU member states of comparable size. On the other hand, all the time a huge distance, one could say civilizational, separated Poland as a country and all regions from the poorest countries and regions of the "old" EU member states. Despite the increase in the pool of the EU funds for eastern voivodships in recent programming periods, the country's economic activity is still concentrated in the main agglomerations, especially Warsaw and the Mazowieckie Voivodship, whose share in the national GDP is almost 22\%. Development differences in the form of the share of particular voivodships in the national GDP are presented in the table below.

Table 2

Share of voivodships in the creation of national GDP in 2013 (the last year of the second programming period, years 2007-2013)

\begin{tabular}{|c|l|c|}
\hline \hline Item & \multicolumn{1}{|c|}{ Voivodeship } & Percentage of GDP \\
\hline 1 & \multicolumn{1}{|c||}{2} & 3 \\
\hline 1. & Mazowieckie & 21.9 \\
\hline 2. & Śląskie & 12.5 \\
\hline 3. & Wielkopolskie & 9.7 \\
\hline 4. & Dolnośląskie & 8.5 \\
\hline 5. & Małopolskie & 7.7 \\
\hline 6. & Lódzkie & 6.1 \\
\hline 7. & Pomorskie & 5.8 \\
\hline 8. & Kujawsko-pomorskie & 4.5 \\
\hline 9. & Lubelskie & 4.0 \\
\hline 10. & Podkarpackie & 3.9 \\
\hline
\end{tabular}




\begin{tabular}{|c|l|c||}
\hline 1 & \multicolumn{1}{|c|}{2} & 3 \\
\hline 11. & Zachodniopomorskie & 3.8 \\
\hline 12. & Warmińsko-mazurskie & 2.7 \\
\hline 13. & Świętokrzyskie & 2.4 \\
\hline 14 & Podlaskie & 2.3 \\
\hline 15. & Lubuskie & 2.2 \\
\hline 16. & Opolskie & 2.1 \\
\hline
\end{tabular}

Source: A compilation based on data from the Central Statistical Office.

According to the presented data, the economically strongest Mazowieckie Voivodeship produces almost a quarter of the Polish GDP. A similar (total) share in GDP is held by two voivodships in second and third place: Śląskie and Wielkopolskie. The eastern and three poorer voivodships located on the western outskirts of Poland (Zachodniopomorskie, Lubuskie and Opolskie voivodships) consistently "stand out." The level of share in the national GDP indicates the potential of individual voivodships. Another important indicator is the level of affluence of the inhabitants expressed as a percentage of GDP per capita in relation to the national average. Developmental disproportions between Polish voivodships in this period were slightly different than the share in the national GDP. This is shown in the table below.

Table 3

GDP per capita in 2013 in individual voivodships expressed as a percentage of the national average

\begin{tabular}{|c|l|l||}
\hline \hline Item & \multicolumn{1}{|c|}{ Voivodeship } & Percentage of GDP \\
\hline 1. & Mazowieckie & 159.1 \\
\hline 2. & Dolnośląskie & 112.1 \\
\hline 3. & Wielkopolskie & 108.0 \\
\hline 4. & Śląskie & 104.2 \\
\hline 5. & Pomorskie & 96.7 \\
\hline 6. & Lódzkie & 93.9 \\
\hline 7. & Małopolskie & 88.3 \\
\hline 8. & Zachodniopomorskie & 84.1 \\
\hline 9. & Lubuskie & 83.7 \\
\hline 10. & Kujawsko-pomorskie & 82.4 \\
\hline 11. & Opolskie & 80.8 \\
\hline 12. & Swiętokrzyskie & 73.0 \\
\hline 13. & Podlaskie & 72.8 \\
\hline 14 & Warmińsko-mazurskie & 72.0 \\
\hline 15. & Podkarpackie & 71.1 \\
\hline 16. & Lubelskie & 70.6 \\
\hline
\end{tabular}

Source: Based on data from the Central Statistical Office.

In 2013, only in four voivodships, the level of GDP per capita was higher than the national average. These voivodships are related to the largest cities in Poland, which have not only the highest GDP per capita in the country but also the highest growth dynamics. In this comparison, similarly as in the case of the share in the national GDP, Mazovia clearly leads. However, this indicator says nothing about intra-regional 
disparities, and the largest ones are in this richest voivodeship. The development dynamics of Warsaw clearly contrast with the stagnation of most of the voivodeship's territory. Thus, the level of GDP per capita in the capital city of Warsaw amounted to $290.7 \%$ of the national average and was four times higher than in the districts of Radom $(72.0 \%)$, Siedlce or Ostroleka $(76.2 \%) .{ }^{2}$ Not so drastically but also intra-regional disparities are visible in the other three voivodships, which exceed the average national GDP level, i.e. in the following regions: Dolnośląskie (112.1\%), Wielkopolskie (108.0\%), Śląskie (104.2\%).

The remaining voivodships had a GDP per capita smaller than the national average. Below 80 per cent were the five poorest Polish voivodeships of the "eastern wall," and the economically weakest for years has been Lubelskie Voivodeship, which with the national average at the level of 70.6 per cent is among the poorest regions of the European Union as a whole.

Difficult to eliminate regional and especially intra-regional disparities created a dilemma: how to conduct regional policy, which after all is an integral part of the economic and social policy of the state, in order to eliminate these disparities? Is it possible to rely solely on a few agglomerations - "growth locomotives?" Or should conditions be created (infrastructure, human resources, ability to absorb support measures) for the activation of weak and weak regional centres? When taking up the issue of regional policy, it should be remembered that the measure of its success will be the inability to achieve a significant increase in diversification not only between regions but also within them, more: to reduce these disproportions. The data presented above shows that EU support for poorer areas stimulated their development, gave them a growth dynamics, but it was not possible to effectively reduce the development gaps in relation to the economically strongest areas, both in the EU and in Poland.

\section{Successes and failures in the implementation of the $E U$ funds for the 2007-2013 programming period}

The largest and most effective group of beneficiaries of structural funds, as already mentioned, were and are local government units. The vast majority of projects implemented by them - about $92 \%$ - were investments in basic infrastructure, which has been neglected for many years. Thanks to investments in transport infrastructure, the transport accessibility of large metropolises, which are poles of economic growth, as well as areas so far poorly accessible in terms of transport, has been gradually improving. This improved people's living conditions and increased Poland's investment attractiveness. On the other hand, projects aimed at modernisation and expansion of the environmental protection infrastructure contributed not only to Poland's implementation of its international commitments but also to the improvement of the condition of nature, the quality of life of its inhabitants, reduction of environmental threats and natural disasters. The funds earmarked for structural transformation in agriculture and fisheries, as well as for the development of rural areas have significantly improved the

\footnotetext{
${ }^{2}$ GUS data.
} 
competitiveness of these sectors and their sustainable development. The development of entrepreneurship in rural areas enabled their inhabitants to take up employment outside the agricultural sector and thus contributed to the reduction of hidden unemployment in rural areas.

The positive impact of aid measures on the development of the country and the quality of life of citizens does not relieve them from identifying misguided projects often dictated by the personal ambitions of local leaders. Seeking the support of voters in subsequent elections, they often undertook over-ambitious investments, exceeding budgetary possibilities. Despite an overall positive assessment of the absorption of the EU funds in Poland, there are plenty of examples of misguided and poorly executed investments. A spectacular example is the construction of an airport in Modlin, which received the largest subsidy (PLN 151 million) out of the investments financed from the Regional Operational Programme for Mazovia, and after half a year was closed due to faulty construction of the runway. Another infrastructural investment project carried out with a long delay (the reason was the need to introduce continuous changes to the already adopted design assumptions) was the construction of the 85-kilometre section of the A1 motorway from Łódź to Kowal. The scale of this project is evidenced by the value of the construction works of the aforementioned section (PLN 2.4 billion), which were co-financed from the Operational Programme Infrastructure and Environment. Similarly, examples of lack of due diligence can be given from the construction of other road sections or railroad repairs.

Very often smaller projects implemented by local governments, such as aquaparks which were undoubtedly socially useful, were not the most needed and pro-development investments in small towns which were becoming depopulated, such as Działdowo. In the future, they will generate costs related to maintenance and not stimulate sustainable growth. An example of this type of investment is also the Intercollegiate Library in Stalowa Wola, which was built at the cost of PLN 26 million and shines empty. Similarly, the baths in Lidzbark Warmiński built at the cost of 96 million, 66 million of which came from the EU funds, turned out to be a total playground. The water extracted to the surface has 21, not 30 degrees Celsius. The Podlasie Opera House in Białystok cost PLN 220 million, with EU funding of PLN 100 million. Built in a city of fewer than 300,000 inhabitants, it has been one of the largest cultural investments in Poland in recent years, with the second largest stage in the country. The annual cost of maintaining the opera is PLN 25 million, of which PLN 5 million will be financed by the Ministry of Culture, PLN 13 million will come from the budget of the Podlaskie Voivodeship, PLN 2 million from the budget of the city of Białystok, and the remaining funds must be provided by the management of the opera. In the following years, it may turn out that Białystok and Podlaskie Voivodeship, one of the poorest in the country, will not be able to maintain this institution. This is all the more so since, as a cultural institution, it will neither generate economic growth in the region nor additional jobs for its inhabitants.

Despite these individual examples of spectacular investments, contrary to common sense, in general, as already mentioned, the implementation of European measures can be considered as successful in Poland. The most important effects of the implementation of structural funds in Poland (from accession to August 2015, $n+2$ rule) include the following undertakings: 
- in the field of transport infrastructure: $10,123 \mathrm{~km}$ of roads, $1,670 \mathrm{~km}$ of railway lines, 2,906 units of public transport fleet;

- in the sphere of entrepreneurship: 409,390 new jobs, 30,956 supported enterprises, 246 supported business support institutions;

- in the field of research and development: 1,412 supported universities and scientific institutions, 644 research centres, 1,909 laboratories, 2,864 supported innovative ideas, 3,736 implemented technologies;

- in the area of the information society: $55,151 \mathrm{~km}$ of the broadband Internet network, 213,650 Internet access for households, 5,780 new e-services;

- in the field of environmental protection: 512 wastewater treatment plants, $24,267 \mathrm{~km}$ sewage network, 7,103 km water supply network, 2,515 investments in renewable energy sources and improvement of energy efficiency. ${ }^{3}$

The implementation of the EU funds has contributed to improving the condition of infrastructure conducive to economic growth, but this positive change will not replace the most important growth factor, i.e. the pro-development policy of the state and human capital development. These and other tasks were undertaken in the current programming period, and the final assessment of their effects will take place only after 2020.

\section{Allocation of funds in the programming period 2014-2020. First summaries}

In the 2014-2020 programming period, Poland has EUR 82.5 billion to invest from the EU cohesion policy by implementing six National Operational Programmes (NOPs) and 16 Regional Operational Programmes (ROPs). The funds are invested in increasing the competitiveness of the Polish economy, improving social and territorial cohesion of the country, in improving the efficiency and effectiveness of administration. The most important objective of the EU programmes of these years is to improve the standard of living of the inhabitants' thanks to the economic growth and increase in employment. The percentage distribution of funds between national and regional operational programmes is $40.7 \%$ for NIP and $59.3 \%$ for ROP. The National Operational Programmes include:

- The Infrastructure and Environment Operational Programme (OP IE), whose objective is to support an economy that is environmentally friendly and conducive to territorial and social cohesion;

- The Smart Growth Operational Programme (SG OP) aims to promote activities aimed at stimulating innovation and competitiveness of the economy by increasing private expenditure on research and development, strengthening links between business and science sectors, development of innovativeness of enterprises, improving the quality of research and the position of national scientific entities within the European Research Area;

- The Knowledge Education Development Operational Programme (OP KED) - aims at supporting the quality and effectiveness of higher education as an instrument for building a knowledge-based economy;

\footnotetext{
${ }^{3}$ Data of the Ministry of Infrastructure and Development.
} 
- Digital Poland Operational Programme (OP DP) - supports the development of information and communication technologies, creation of broadband networks and development of public e-services;

- Eastern Poland Operational Programme (OP EP) - an additional instrument of support for improving the competitive position of Eastern Poland by improving the level of innovativeness of the economy, development of labour markets in the main urban centres;

- Technical Assistance Operational Programme (OP TA) - supporting the efficiency of the cohesion policy funds implementation system.

The method of distribution of funds for particular National Operational Programmes is presented in Table 4 below.

Table 4

Distribution of resources from the Structural Funds and the Cohesion Fund among the national operational programmes for the years 2014-2020

\begin{tabular}{||l|c|c|}
\hline \multicolumn{1}{|c|}{ Operational Programme } & In billions of euros & Percentage \\
\hline Infrastructure and Environment & 27.41 & 60.1 \\
\hline Smart Growth & 8.61 & 18.9 \\
\hline Knowledge of Education Development & 4.69 & 10.3 \\
\hline Digital Poland & 2.17 & 4.8 \\
\hline Eastern Poland & 2.0 & 4.4 \\
\hline Technical Assistance & 0.7 & 1.5 \\
\hline Total & 45.58 & 100.0 \\
\hline
\end{tabular}

Source: Own elaboration based on data from the Ministry of Investment and Development.

The largest amount of funds was allocated to the Infrastructure and Environment Programme, i.e. support for activities in favour of a low-carbon economy, environmental protection, development of the country's technical infrastructure and strengthening energy security. The second largest grant is the Intelligent Development Programme, which supports research, development and innovation. The main objective of this programme is to co-finance innovation from the moment the concept of producing unparalleled products, services or technologies is created, through the preparation of prototypes/pilot lines, to their commercialisation. On the other hand, the objective of the Knowledge Development Education Programme is the professional activation of people under 30 years of age, support for higher education, development of social innovations, mobility and transnational cooperation, as well as strengthening employment, social inclusion, education, health and good governance policies. On the other hand, the Digital Poland Programme, with a pool of over EUR 2 billion, is aimed at increasing access to the Internet, improving e-administration (which will popularise electronic handling of official matters) and educating the whole society about how to function online. The Eastern Poland Programme is a supra-regional programme for Eastern Poland voivodships aimed at increasing their competitiveness and innovativeness. Efficient implementation of funds and support for the system of information and promotion of European funds is to be ensured by the Technical Assistance Programme. 
In turn, the objective of the 16th Regional Operational Programmes (ROPs) is to increase the competitiveness of the regions, improve the quality of life of the inhabitants by using the existing potentials and reducing developmental barriers. Support for entrepreneurship, education, employment, social inclusion, information and communication technologies, environmental protection infrastructure, energy and transport have been identified as the priorities of these programmes. ROPs are financed from the European Regional Development Fund (ERDF) and the European Social Fund (ESF).

The table below presents the division of funds between particular ROPs.

Table 5

Division of structural funds into Regional Operational Programmes for 2014-2020

\begin{tabular}{||l|c|c|}
\hline \hline Regional Operational Programme & EUR billion & \% \\
\hline Dolnośląskie & 2.2 & 7.1 \\
\hline Kujawsko-pomorskie & 1.9 & 6.1 \\
\hline Lubelskie & 2.2 & 7.1 \\
\hline Lubuskie & 0.9 & 2.9 \\
\hline Łódzkie & 2.2 & 7.1 \\
\hline Małopolskie & 2.9 & 9.3 \\
\hline Mazowieckie & 2.1 & 6.8 \\
\hline Opolskie & 0.9 & 2.9 \\
\hline Podkarpackie & 2.1 & 6.8 \\
\hline Podlaskie & 1.2 & 3.9 \\
\hline Pomorskie & 1.9 & 6.1 \\
\hline Śląskie & 3.5 & 11.3 \\
\hline Świętokrzyskie & 1.4 & 4.5 \\
\hline Warmińsko-mazurskie & 1.7 & 5.5 \\
\hline Wielkopolskie & 2.4 & 7.7 \\
\hline Zachodniopomorskie & 1.6 & 5.1 \\
\hline Total & 31.1 & 100,0 \\
\hline
\end{tabular}

Source: Own elaboration based on data from the Ministry of Investment and Development.

The highest percentage of funds was allocated to the Śląskie and Małopolskie Voivodships. On the other hand, the smallest pool of funds was allocated to Lubuskie and Opolskie voivodships. The poorest Polish voivodships were allocated between 4 and 7 per cent of the total amount for regional programmes, but these regions were reinforced with the sum of EUR 2 billion from the National Operational Programme Eastern Poland. At this point it is worth noting that, according to Eurostat data, in 2017, among the 20 poorest regions of the European Union (below 50\% of the EU average GDP per capita, according to purchasing power standards) there were three Polish voivodeships: Podkarpackie (49\%), Warmińsko-Mazurskie (49\%) and Lubelskie (48\%), while two voivodeships previously included in this group, Świętokrzyskie and Podlaskie, were promoted slightly exceeding 50\% of the average GDP in the EU (Newsrelease, 2019). On the other hand, a year earlier, in 2016, the lowest ranked among the Polish voivodships was the Lubelskie voivodship with $47 \%$ of the average EU GDP per capita. Podkarpackie and Podlaskie voivodships were ranked slightly higher, 48\% each, and Świętokrzyskie and 
Warmińsko-Mazurskie voivodships were ranked slightly higher, 49\% each (Eurostat, 2017). Similar indicators were recorded in 2015 (Eurostat, 2016). These data indicate that the purchasing power of Polish regions, including the poorest ones, improves with each year, although not to a satisfactory extent, compared to the EU average.

The above mentioned eastern Polish regions (DEP OP) ${ }^{4}$ are catching up, but unfortunately to a very small extent and very slowly their developmental disproportions in relation to the richest Polish and European counterparts. This state of affairs is caused by many factors, both those that occur throughout the EU and those that are indigenous. Thus, the regions of eastern Poland are becoming depopulated, their population is ageing, the number of people of working age is decreasing, the level of innovation is low and the infrastructure is still insufficiently developed. These processes, to a greater or lesser extent, concern not only the aforementioned but also most of the Polish voivodeships. Only the Mazowieckie Voivodeship (mainly due to Warsaw) is approaching the level of social and economic development of the "old" EU regions, and its GDP has already exceeded $75 \%$ of the EU average.

The 2014-2020 programming period has already exceeded its halfway point and is slowly approaching its end, and although according to the data of the Ministry of Investment and Development (Ministry of Investment and Development), in mid-2018 $59.2 \%$ of the funds allocated to Poland under the cohesion policy were used, as indicated by the Supreme Chamber of Control, the implementation of programmes from structural funds has been carried out in a very diversified manner.

One can boast (as of 30 June 2017): construction, reconstruction or modernization of $119 \mathrm{~km}$ of roads, support for over 379 thousand unemployed people, granting subsidies to 1025 enterprises in the form of financial transfers for the implementation of: innovation, improvement of energy efficiency, introduction of new products and undertaking research and development activities. It is undoubtedly a success that 3,884 new places of pre-school education and childcare were created, over 115,000 students participating in internships and apprenticeships at the employer's, and 31,577 students at risk of poverty or social exclusion were supported (Zarzadzanie, 2018, p. 33). However, all these data are less impressive in relation to the results of the 2007-2013 programming period. At that time, funds were focused on infrastructural tasks and the 2014-2020 programming period aims at improving the standard of living of the inhabitants, but these (certainly justified) social transfers, strengthened by the actions of the Polish government, during the good global economic situation, will not build the competitiveness of Polish regions. The Ministry of Infrastructure and Development announces that we are among the top ten EU countries which make the best use of European funds to the greatest extent. The fact that in the previous programming period we were at the forefront and, depending

${ }^{4}$ The Operational Program Development of Eastern Poland was implemented in the years 2007-2013. It was a trans-regional venture, unique in the scale of the European Union. It was aimed at strengthening the social and economic development of the poorest five voivodships of Eastern Poland: Lubelskie, Podkarpackie, Podlasie, Świętokrzyskie and Warmian-Masurian. The OP DEP in its assumptions was to lead to the equalization of development opportunities by modernizing the economies and strengthening the social sphere of these regions. Its resources (around EUR 2.8 billion) were mainly supported by projects related to the development of university infrastructure, support for innovation, facilitating access to the Internet, development of cities, construction of roads and bypasses and development of tourism. 
on the measurement method, we ranked between the first and third place, always on the podium, is silent. The current situation does not inspire optimism all the more because the current programming period 2014-2020 is the last one in which Poland received such significant financial transfers from the European Union.

\section{Conclusion}

In order to maintain and strengthen the pace of pro-development changes in the current programming period of 2014-2020, it was necessary to strengthen the civil service division deciding about European transfers and intellectual resources of the academic community, which had been postulated many times. This postulate was not fulfilled. Today we have to ask questions and try to find answers to the following questions: what will our country, regions and local communities look like after 2020, i.e. after the closure of this modern European Marshall Plan? What strategic objectives have we achieved with European funding? In which areas have we gained a competitive advantage and modernised the country? What should be done in future programming periods to make better use of these already slimmer funds? Looking for an answer to the above-mentioned issues, it is important to make broad social groups and decisionmaking circles aware of the fact that regional development cannot only be managed and controlled but above all, it must be created. Therefore, the inclusion in the process of regional development of people creating, processing and transferring knowledge, i.e. the academic environment, maybe a new beginning in the process of making accurate, wise decisions at the level of voivodships.

\section{Bibliography}

5 lat członkostwa Polski w Unii Europejskiej (2009), Urząd Komitetu Integracji Europejskiej, Warszawa.

Eurostat regional yearbook 2017, Publications Office of the European Union, Luxembourg 2017.

Eurostat regional yearbook 2016, Publications Office of the European Union, Luxembourg 2016.

Narodowe Strategiczne Ramy Odniesienia lata 2007-2013, Ministerstwo Rozwoju Regionalnego, Warszawa, maj 2007.

Newsrelease, 34/2019, GDP per capita in 281 EU regions Regional GDP per capita ranged from $31 \%$ to 626\% of the EU average in 2017, Eurostat, 26 February 2019.

Ocena korzyści uzyskiwanych przez państwa UE-15 w wyniku realizacji polityki spójności w krajach Grupy Wyszehradzkiej, Instytut Badań Strukturalnych, Warszawa, grudzień 2011.

Polityka bezpieczeństwa informacji dla Krajowego Systemu Informatycznego SIMIK 07-13, Ministerstwo Rozwoju Regionalnego.

Raport POLSKA 2011. Gospodarka - społeczeństwo - regiony, Ministerstwo Rozwoju Regionalnego, Warszawa, czerwiec 2011.

Raport Strategiczny 2012, Ministerstwo Rozwoju Regionalnego, Warszawa 2012.

Stan wdrażania programów operacyjnych realizowanych w latach 2007-2013. Perspektywa regionalna, „Przegląd Regionalny”, nr 5, Ministerstwo Rozwoju Regionalnego, Departament Programów Ponadregionalnych, Warszawa, październik 2010. 
Przygotowanie systemu wdrażania polityki strukturalnej na lata 2014-2020, Informacja o wynikach kontroli, KAP-4101-001-00/2014 Nr ewid. 151/2014/P/14/003/KAP, NIK Warszawa 2014.

Sujkowska Z. (2005), Phare: założenia, projekty, rezultaty, Zakład Europeistyki Instytutu Studiów Politycznych PAN, Europejskie Centrum Przedsiębiorczości, Warszawa.

Sujkowska Z. (2013), Przemiany w Polsce po akcesji do Unii Europejskiej, Dom Wydawniczy „Elipsa", Warszawa.

Wpływ funduszy europejskich na gospodarkę polskich regionów i konwergencję z krajami UE. Raport 2010, Ministerstwo Rozwoju Regionalnego, Warszawa 2010.

Wydatki strukturalne w Polsce w latach 2003-2010 wraz z prognoza na lata 2011-2020, PricewaterhouseCoopers (PwC), luty 2012.

Życki A. (2005), Polityka regionalna. Konieczność decentralizacji, "Przegląd Organizacji”, nr 10.

\section{Summary}

The author summarizes the implementation of regional policy 15 years after Poland's accession to the EU as revealed in the official data coming from Polish regions, the Ministry of Investment and Development, the European documents and his own expert experience. Not only does he indicate the legitimacy of the adopted directions of intervention, but also he analyses the examples of misuse of EU funds. The latter cases, according to the author, are often associated with local politics, when investment decisions are based on current electoral calculations, and not long-term development strategy. The recommendations propose a change of the hitherto dominant compensatory model of the implementation of European funds to a modernisation model using knowledge as the main development component. This is also related to the need for a broader involvement of the academic community in regional policy.

Key words: cohesion policy, the Structural Funds, European integration, infrastructure investments, government

\section{Rozwój regionalny stymulatorem konkurencyjności Polskiej gospodarki}

\section{Streszczenie}

Autor, opierając się na oficjalnych danych z polskich regionów, Ministerstwa Inwestycji i Rozwoju oraz dokumentów europejskich i własnych doświadczeniach eksperckich podsumowuje wdrażanie polityki regionalnej po 15. latach od akcesji Polski do UE. Wskazuje na zasadność przyjętych kierunków interwencji, ale też poddaje analizie przykłady niewłaściwego wykorzystania unijnych środków. Te ostatnie przypadki, zdaniem autora, często związane są z samorządową polityką, kiedy decyzje inwestycyjne wynikają z bieżącej kalkulacji wyborczej, a nie długofalowej strategii rozwoju. W rekomendacjach zaproponowano zmianę dominującego dotychczas wyrównawczego modelu implementacji europejskich środków na model modernizacyjny z wykorzystaniem wiedzy jako głównego składnika rozwojowego. Wiąże się z tym również potrzeba szerszego zaangażowania w politykę regionalną środowiska akademickiego.

Słowa kluczowe: polityka spójności, fundusze strukturalne, integracja europejska, inwestycje infrastrukturalne, rząd 
